J. Dairy Sci. 99:7319-7329

http://dx.doi.org/10.3168/jds.2016-10989

(C) American Dairy Science Association ${ }^{\circledR}, 2016$.

\title{
Effects of injectable trace mineral supplementation in lactating dairy cows with elevated somatic cell counts
}

\author{
E. K. Ganda, R. S. Bisinotto, ${ }^{1}$ A. K. Vasquez, A. G. V. Teixeira, V. S. Machado, C. Foditsch, M. Bicalho, \\ F. S. Lima, ${ }^{2}$ L. Stephens, M. S. Gomes, ${ }^{2}$ J. M. Dias, and R. C. Bicalho ${ }^{3}$ \\ Department of Population Medicine and Diagnostic Sciences, College of Veterinary Medicine, Cornell University, Ithaca, NY 14853
}

\section{ABSTRACT}

Objectives of this clinical trial were to evaluate the effects of injectable trace mineral supplementation (ITMS) on somatic cell count (SCC), linear score (LS), milk yield, milk fat and protein contents, subclinical mastitis cure, and incidence of clinical mastitis in cows with elevated SCC. Holstein cows from a commercial dairy farm in New York were evaluated for subclinical mastitis, defined as SCC $\geq 200 \times 10^{3}$ cells $/ \mathrm{mL}$ on the test day preceding enrollment. Cows with a history of treatment for clinical mastitis in the current lactation and those pregnant for more than $150 \mathrm{~d}$ were not eligible for enrollment. Cows fitting inclusion criteria were randomly allocated to 1 of 2 treatment groups. Cows assigned to ITMS $(\mathrm{n}=306)$ received 1 subcutaneous injection containing zinc (300 mg), manganese (50 mg), selenium $(25 \mathrm{mg})$, and copper $(75 \mathrm{mg})$ at enrollment (d 0). Control cows (CTRL; $\mathrm{n}=314$ ) received 1 subcutaneous injection of sterile saline solution. Following treatment, visual assessment of milk was performed daily, and cows with abnormal milk (i.e., presence of flakes, clots, or serous milk) were diagnosed with clinical mastitis (CM). Chronic clinical mastitis was defined as cows with 3 or more cases of CM. Milk yield, milk fat and protein contents, SCC, and LS were evaluated once monthly. Additionally, randomly selected animals were sampled to test serum concentrations of selected minerals on $\mathrm{d} 0$ and 30 ( $\mathrm{n}=30$ cows/treatment). Treatment did not affect serum concentrations of calcium, magnesium, phosphorus, potassium, copper, iron, manganese, selenium, and zinc on d 30. Injectable supplementation with trace minerals did not improve

\footnotetext{
Received February 4, 2016.

Accepted May 17, 2016.

${ }^{1}$ Current address: Department of Veterinary Population Medicine, University of Minnesota, St. Paul, MN 55108.

${ }^{2}$ Current address: Department of Veterinary Clinical Medicine, Veterinary Teaching Hospital, University of Illinois at UrbanaChampaign, Urbana, IL 61802.

${ }^{3}$ Corresponding author: rcb28@cornell.edu
}

overall cure of subclinical mastitis $(\mathrm{CTRL}=42.8$ vs. ITMS $=46.5 \%$, although a tendency was observed in cows with 3 or more lactations $(\mathrm{CTRL}=27.1$ vs. ITMS $=40.0 \%)$. Supplementation did not reduce treatment incidence of CM (CTRL $=48.2$ vs. ITMS $=41.7 \%$ ); however, it tended to reduce the proportion of cows diagnosed with chronic $\mathrm{CM}(\mathrm{CTRL}=16.9$ vs. ITMS $=$ $12.0 \%$ ), particularly among first-lactation cows (CTRL $=18.4$ vs. ITMS $=7.6 \%$ ). Cure of subclinical mastitis was associated with higher serum concentrations of phosphorus and selenium on d 30. Supplementing trace minerals to cows with elevated SCC had no effect on milk yield, milk fat and protein contents, SCC, and LS. Key words: mastitis, udder health, zinc, manganese, selenium

\section{INTRODUCTION}

Mastitis remains a highly prevalent disease in dairy herds and leads to major economic losses to the dairy industry worldwide, with each clinical case being estimated to cost between $\$ 179$ and $\$ 488$ (Bar et al., 2008; Hagnestam-Nielsen and Ostergaard, 2009). Despite the absence of clinical signs and visible changes in milk, subclinical mastitis (SCM), commonly diagnosed through an increase in SCC, is also extremely costly to dairy herds. Cows with SCM produce up to $4.6 \mathrm{~kg} / \mathrm{d}$ less milk compared with healthy herdmates (Green et al., 2006; Halasa et al., 2009; Boland et al., 2013), represent a reservoir of infection for other cows in the herd (White et al., 2006), and are at a greater risk of being culled or developing clinical mastitis (CM; Deluyker et al., 1993; Barlow et al., 2009).

Ensuring adequate trace mineral availability is a potential strategy to reduce the effects of high SCC. Trace minerals are critical for proper immune response and play an important role in udder health. Selenium is a component of the antioxidant enzyme glutathione peroxidase and selenium-deficient dairy cows have impaired neutrophil function in blood (Hogan et al., 1990) and milk (Grasso et al., 1990). Elevated concentrations of selenium in blood are associated with reduced preva- 
lence of IMI and reduced bulk tank SCC (Erskine et al., 1987; Weiss et al., 1990; Kommisrud et al., 2005). Additionally, copper and zinc are essential for bovine superoxide dismutases, enzymes responsible for catalyzing superoxide radicals into oxygen and hydrogen peroxide. Dietary copper has been associated with neutrophil-killing activity in dairy cattle (Torre et al., 1996). Dairy heifers fed peripartum diets supplemented with copper had lower bacterial counts and SCC in milk following an intramammary challenge with Escherichia coli compared with counterparts fed a diet with marginal copper content (Scaletti et al., 2003).

Although diets formulated to meet the NRC (2001) recommendations are expected to provide adequate amounts of trace minerals, nutrient interactions within the rumen, reduced appetite, restricted access to the feed bunk, and absorptive disorders might limit their intake or bioavailability. Conversely, 2 subcutaneous injections of a mineral solution in prepartum dairy cows sustained elevated serum concentrations of copper, selenium, and zinc for approximately $14 \mathrm{~d}$ following the last treatment (Bicalho et al., 2014). Interestingly, cows diagnosed with metritis had lower selenium and zinc concentrations in serum during early postpartum compared with healthy herdmates (Bicalho et al., 2014). Previous results indicate that the use of the same injectable trace mineral supplementation during the transition period improved udder health in dairy cows. Supplementation performed at 230 and $260 \mathrm{~d}$ of gestation and at 35 DIM reduced the incidence of clinical mastitis and SCC in multiparous cows (Machado et al., 2013). These results suggest that cows undergoing stress caused by infectious diseases have lower levels of selenium and zinc, and that restoring endogenous pools might be associated with cure. The effects of injectable trace minerals in cows previously diagnosed with SCM remains to be determined. For that reason, determining to what extent each mineral is affected in cows with elevated SCC and whether or not increasing circulating concentrations of trace minerals is associated with reduction of SCC is expected to provide valuable information for the treatment of SCM.

The hypothesis of the present study was that injectable trace mineral supplementation would improve udder health in dairy cows diagnosed with SCM. Our objectives were (1) to evaluate the effects of an injectable trace mineral supplementation containing selenium, copper, zinc, and manganese on SCC, linear score (LS), milk yield and composition, incidence of $\mathrm{CM}$, and SCM cure in cows previously diagnosed with SCM, as well as (2) to investigate the extent in which minerals are affected in dairy cows with elevated SCC.

\section{MATERIALS AND METHODS}

\section{Animal Care Statement}

The experimental procedures were carried out according to the research protocol 2013-0056, that was reviewed and approved by the Institutional Animal Care and use Committee of the Cornell University.

\section{Farm and Management}

This study was conducted on a single commercial dairy farm located in upstate New York. During the experimental period, the farm milked approximately 3,000 cows. In total, 620 Holstein cows were enrolled in the study from January 10 to April 8, 2014. Primiparous and multiparous cows were housed separately in freestall barns with concrete stalls covered with mattresses and bedded with manure solids. Cows were fed a TMR to meet or exceed the nutrient requirements of a $650-\mathrm{kg}$ lactating Holstein cow producing $45 \mathrm{~kg} / \mathrm{d}$ of milk with $3.5 \%$ fat and $3.2 \%$ true protein when DMI is $25 \mathrm{~kg} / \mathrm{d}$ (NRC, 2001). Fifteen feed samples were collected at the feed bunk, pooled, and submitted for analysis at the DairyOne Laboratory (DairyOne Laboratories, Ithaca, NY). Diet composition is presented in (Table 1). Cows were milked thrice daily in a double-52 milking parlor. The farm participated in DHIA and all lactating cows were tested for SCC and milk composition once monthly.

Table 1. Total mixed ration analysis

\begin{tabular}{lc}
\hline Item & DM \\
\hline CP (\%) & 15.6 \\
Soluble protein (\%) & 52.0 \\
ADF (\%) & 22.4 \\
Amylase-treated NDF (\%) & 36.4 \\
Lignin (\%) & 2.90 \\
Nonfibrous carbohydrates (\%) & 37.0 \\
Starch (\%) & 27.6 \\
Crude fat $(\%)$ & 4.00 \\
Ash (\%) & 6.99 \\
TDN (\%) & 72.0 \\
NE (Mcal/kg) & 1.67 \\
Calcium (\%) & 0.71 \\
Phosphorus (\%) & 0.42 \\
Magnesium (\%) & 0.24 \\
Potassium (\%) & 1.58 \\
Sodium (\%) & 0.40 \\
Iron (mg/kg) & 234 \\
Zinc (mg/kg) & 60.0 \\
Copper (mg/kg) & 12.0 \\
Manganese (mg/kg) & 40.0 \\
Molybdenum (mg/kg) & 1.00 \\
Selenium (mg/kg) & 0.49 \\
\hline
\end{tabular}




\section{Enrollment Criteria and Case Definitions}

Lactating dairy cows that had SCC $\geq 200 \times 10^{3}$ cells/ $\mathrm{mL}$ in the closest DHIA test to enrollment, were less than $150 \mathrm{~d}$ pregnant, and had not received intramammary antibiotic therapy in the current lactation were eligible for enrollment. Milk sampling was performed by DHIA personnel and assayed using flow cytometry (DairyOne Laboratories, Ithaca, NY). Subclinical mastitis was defined as SCC $\geq 200 \times 10^{3}$ cells $/ \mathrm{mL}$ and $\mathrm{SCM}$ cure was defined for cows with $\mathrm{SCC}<200 \times 10^{3}$ cells/ $\mathrm{mL}$ on the first monthly DHIA test following enrollment. Clinical mastitis was defined based on visual evaluation of milk in a forestripping test performed by trained farm personnel. Clinical mastitis was defined based on visual evaluation of milk in a forestripping test performed every milking by trained farm personnel. Cows with presence of flakes, clots, or serous milk were diagnosed with CM independent of systemic illness and signs of inflammation in the mammary gland. Cows diagnosed with $\mathrm{CM}$ were moved to the hospital pen and treated according to the study site's standard procedures. Chronic CM was defined as cows with 3 or more cases of $\mathrm{CM}$ after enrollment.

\section{Experimental Design and Treatments}

This study was conducted as a complete randomized design and cows were enrolled on a monthly basis. A total of 620 cows were included in the study, from which $240(38.7 \%)$ were in the first lactation, $215(34.7 \%)$ were in the second lactation, and $165(26.6 \%)$ were in the third or later lactations. Cows diagnosed with SCM were randomly allocated to 1 of 2 treatments based on a list generated using the RAND function of Excel (Microsoft Corp., Redmond, WA). On the day of enrollment, henceforth defined as study d 0, cows assigned to receive injectable trace mineral supplementation (ITMS; $\mathrm{n}=306$ ) were treated once subcutaneously in the ischiorectal fossa with $5 \mathrm{~mL}$ of an injectable trace mineral solution containing zinc (300 $\mathrm{mg}$ ), manganese (50 mg), selenium (25 mg), and copper (75 mg; Multimin 90, Multimin North America Inc., Fort Collins, $\mathrm{CO}$ ). Cows assigned to the control group (CTRL; $\mathrm{n}=$ 314) received a subcutaneous injection of sterile saline solution of the same volume $(5 \mathrm{~mL})$.

\section{Sampling and Data Collection}

Blood samples were collected from a randomly selected subset of cows ( $\mathrm{n}=30 /$ treatment) before injection of trace mineral supplementation on $\mathrm{d} 0$ and again on $\mathrm{d}$ 30 for the analysis of mineral concentrations. Blood was sampled by puncture of coccygeal vessels into evacu- ated tubes without anticoagulant (Becton Dickinson, Franklin Lakes, NJ). Blood tubes were placed on ice and centrifuged at $2,000 \times g$ for $15 \mathrm{~min}$ at $4^{\circ} \mathrm{C}$ for serum separation within $5 \mathrm{~h}$ of collection. Serum samples were frozen at $-80^{\circ} \mathrm{C}$ until assayed.

Individual milk production was measured using onfarm milk meters (ALPRO, DeLaval, Tumba, Sweden) once monthly during the DHIA test day. Milk fat and protein contents were measured using Fourier transform infrared spectroscopy (MilkoScan, Eden Prairie, MN). Somatic cell counts were determined by flow cytometry (Fossomatic FC, Eden Prairie, MN). Linear scores were calculated based on SCC as follows:

$$
\mathrm{LS}=\left[\ln \left(\mathrm{SCC} / 100 \times 10^{3}\right) / 0.693147\right]+3 .
$$

Body condition score was evaluated on d 0 using a 5 -point scale with quarter-point increments as described by (Edmonson et al., 1989) for Holstein cows.

Follow-up data were retrieved from the study site's farm management software (DC305, Valley Agricultural Software, Tulare, CA). Somatic cell count, milk production, milk composition, and $\mathrm{CM}$ events were recorded for 10 mo after enrollment (follow-up period) or until culling or drying off.

\section{Analysis of Mineral Concentrations in Serum}

Serum concentrations of calcium, magnesium, phosphorus, copper, iron, potassium, manganese, molybdenum, selenium, and zinc were determined by mass spectrometry (Varian 820-MS, Varian Inc., Palo Alto, $\mathrm{CA}$ ) at the Veterinary Diagnostic Laboratory (Iowa State University, Ames, IA).

\section{Statistical Analyses}

Sample size calculation was performed using the POWER procedure of SAS version 9.3 (SAS/STAT, SAS Institute Inc., Cary, NC). A total of 300 cows per treatment was deemed necessary to detect a 10 percentage point increase in the proportion of cows cured from SCM with $\alpha=0.05$ and $\beta=0.20$. Descriptive statistical analyses were performed using JMP version 11 (SAS Institute Inc.) for all following variables at enrollment: BCS, DIM, lactation number, days from sampling to treatment, milk yield, milk fat percentage, milk protein percentage, SCC, and LS.

To evaluate the effect of treatment on the binary outcomes such as SCM cure and incidences of CM and chronic CM, logistic regression was performed using the LOGISTIC and GLIMMIX procedures of SAS. The fixed effects of treatment, lactation group (1,2, and $\geq 3$ lactations), and the interaction between treatment 
and lactation group were included as independent variables in the statistical models. Results were presented as proportions and adjusted odds ratios relative to a reference group.

Continuous outcomes were analyzed by ANOVA fitting a normal distribution. Visual assessment of the distribution of studentized residuals and $\mathrm{Q}-\mathrm{Q}$ plots was performed for each dependent variable to ensure normality of residuals and homogeneity of variances. Concentrations of minerals in serum on study d 0 and 30 were analyzed in separate models using the GLIMMIX procedure of SAS. The models included the fixed effects of treatment, lactation group, and the interaction between treatment and lactation group. For analyses of mineral concentrations on d 30, data from d 0 were used as covariate. Tukey-adjusted pairwise comparisons between lactation groups were performed for mean mineral concentrations at enrollment.

To evaluate the effect of treatment in milk yield, milk fat and protein contents, SCC, and LS, ANOVA for repeated measures was performed using the MIXED procedure of SAS. The fixed effects of treatment, lactation group, time, and the interactions between treatment and time, treatment and lactation group, lactation group and time, and treatment, lactation group, and time were included as independent variables into the statistical models. To control for repeated measurements, cow was considered a random effect. $P$-values were adjusted using the method of Tukey for pairwise comparisons. The first-order autoregressive structure of covariance was used in all analyses because it resulted in the lowest Schwarz's Bayesian information criterion value. Results are presented as least squares means \pm standard error of the mean.

The effect of injectable trace mineral supplementation on enrollment to removal from the herd interval was analyzed by Kaplan-Meier survival analysis using MedCalc version 12.2.1.0 (MedCalc Software, Ostend, Belgium). Treatment was included in the statistical model as an independent variable and $P$-values were calculated using the Logrank test For cows that were removed from the herd, right censoring was performed based on date of removal; for all other animals, censoring was done based on follow-up period (date of dry off). For all statistical models, $P$-value $\leq 0.05$ were considered significant and those with $0.05<P \leq 0.10$ were considered tendencies.

\section{RESULTS}

\section{Descriptive Statistics}

Body condition score, DIM, lactation number, milk yield and composition, SCC, and LS at enrollment did not differ between treatments (Table 2).

\section{Mineral Concentrations in Serum}

With the exception of calcium and manganese concentrations, which were higher in CTRL compared with ITMS cows, mineral concentrations in serum did not differ between treatments on d 0 (Table 3). Serum concentrations of molybdenum tended to be higher $(P$ $=0.09)$ in CTRL compared with ITMS cows on d 30 (Table 3). Nevertheless, the remaining macro and trace minerals evaluated on d 30 were not affected by treatment. Initial serum concentrations of copper, phosphorus, and calcium differed between lactation groups (Table 3). First-lactation cows had higher $(P \leq 0.05)$ circulating concentrations of calcium and phosphorus compared with multiparous cows. In addition, copper and calcium concentrations were lower $(P \leq 0.05)$ in cows with 3 or more lactations.

\section{Udder Health, Cure of SCM, and Incidence of CM}

Injectable trace mineral supplementation did not affect SCC during the follow-up period. Somatic cell count was lower $(P<0.01)$ for first-lactation cows, followed by cows in the second lactation and those with 3 or more lactations $(551 \pm 43,800 \pm 50$, and 1,043 \pm 55 $\times 10^{3}$ cells $/ \mathrm{mL}$, respectively). The interaction between treatment and lactation group did not affect SCC. In a similar fashion, treatment and the interaction between treatment and lactation group did not affect LS, which were also lower $(P<0.01)$ for first-lactation cows, followed by cows in the second lactation and those with 3 or more lactations $(4.0 \pm 0.1,4.6 \pm 0.1$, and $5.1 \pm 0.1$, respectively).

The overall proportion of cows cured from SCM was $46.3 \%(287 / 620)$, whereas the incidences of CM and chronic CM were $44.4(275 / 620)$ and $14.4 \%$ (89/620), respectively. Supplementing cows with injectable trace minerals did not improve overall cure of SCM compared with nonsupplemented controls (Table 4). However, a significant effect of parity on cure of SCM was observed; cure of SCM was greater for first-lactation cows compared with those in the second lactation and 3 or more lactations $(P<0.01)$. The analysis within lactation group depicted a tendency $(P=0.08)$ for injectable trace mineral supplementation to increase SCM cure in cows with 3 or more lactations. Treatment, lactation group, and their interaction did not affect the incidence of CM (Table 5). Nevertheless, injectable trace mineral supplementation tended to reduce $(P=0.09)$ the overall incidence of chronic CM (Table 6). Although lactation group had no effect on the proportion of cows diagnosed with chronic $\mathrm{CM}$, the interaction between treatment and lactation group tended to affect $(P=$ $0.06)$ the incidence of the disease. The proportion of 
Table 2. Descriptive statistics for cows enrolled in the study by treatment group

\begin{tabular}{|c|c|c|c|}
\hline \multirow[b]{2}{*}{ Variable } & \multicolumn{2}{|c|}{ Treatment $^{1}$} & \multirow[b]{2}{*}{$P$-value } \\
\hline & CTRL $(\mathrm{n}=314)$ & ITMS $(\mathrm{n}=306)$ & \\
\hline Enrolled animals, lactation $=1$ & 109 & 131 & 0.08 \\
\hline Enrolled animals, lactation $=2$ & 120 & 95 & \\
\hline Enrolled animals, lactation $\geq 3$ & 85 & 80 & \\
\hline $\mathrm{BCS}$ & $3 \pm 0.2$ & $3 \pm 0.2$ & 0.52 \\
\hline $\mathrm{DIM}^{2}$ & $144.4 \pm 7.1$ & $152.0 \pm 7.2$ & 0.45 \\
\hline Days from sampling to treatment & $7.34 \pm 0.1$ & $7.45 \pm 0.1$ & 0.57 \\
\hline Milk yield $^{2}(\mathrm{~kg})$ & $37.8 \pm 0.5$ & $37.1 \pm 0.5$ & 0.35 \\
\hline Lactation $=1$ & $33.4 \pm 0.8$ & $33.7 \pm 0.7$ & 0.77 \\
\hline Lactation $=2$ & $39.4 \pm 0.8$ & $38.9 \pm 0.9$ & 0.75 \\
\hline Lactation $\geq 3$ & $40.7 \pm 0.9$ & $40.0 \pm 0.9$ & 0.58 \\
\hline Milk fat ${ }^{2}(\%)$ & $4.08 \pm 0.04$ & $4.00 \pm 0.04$ & 0.18 \\
\hline Lactation $=1$ & $4.19 \pm 0.07$ & $4.00 \pm 0.06$ & 0.05 \\
\hline Lactation $=2$ & $4.10 \pm 0.08$ & $4.08 \pm 0.09$ & 0.89 \\
\hline Lactation $\geq 3$ & $3.93 \pm 0.07$ & $3.90 \pm 0.07$ & 0.73 \\
\hline Milk protein $\overline{2}^{2}(\%)$ & $3.17 \pm 0.01$ & $3.15 \pm 0.02$ & 0.48 \\
\hline Lactation $=1$ & $3.18 \pm 0.03$ & $3.14 \pm 0.03$ & 0.40 \\
\hline Lactation $=2$ & $3.22 \pm 0.03$ & $3.22 \pm 0.03$ & 0.96 \\
\hline Lactation $>3$ & $3.11 \pm 0.03$ & $3.11 \pm 0.03$ & 0.94 \\
\hline $\mathrm{SCC}^{2}\left(\times 10^{3}\right.$ cells $\left./ \mathrm{mL}\right)$ & $922.0 \pm 67.3$ & $885.0 \pm 68.2$ & 0.69 \\
\hline Lactation $=1$ & $852.7 \pm 99.4$ & $689.3 \pm 90.6$ & 0.22 \\
\hline Lactation $=2$ & $855.1 \pm 110.7$ & $1,096.5 \pm 124.5$ & 0.14 \\
\hline Lactation $\geq 3$ & $1,105.3 \pm 146.2$ & $954.0 \pm 150.8$ & 0.47 \\
\hline Linear score ${ }^{\overline{2}}$ & $5.5 \pm 0.1$ & $5.4 \pm 0.1$ & 0.34 \\
\hline Lactation $=1$ & $5.5 \pm 0.1$ & $5.2 \pm 0.1$ & 0.09 \\
\hline Lactation $=2$ & $5.4 \pm 0.1$ & $5.6 \pm 0.1$ & 0.31 \\
\hline Lactation $\geq 3$ & $5.7 \pm 0.1$ & $5.5 \pm 0.1$ & 0.36 \\
\hline
\end{tabular}

${ }^{1} \mathrm{CTRL}=$ cows received no trace mineral supplementation; ITMS $=$ cows received a single injectable trace mineral supplementation containing zinc $(300 \mathrm{mg})$, manganese $(50 \mathrm{mg})$, selenium $(25 \mathrm{mg})$, and copper $(75 \mathrm{mg})$ at enrollment. Results presented as LSM \pm SEM.

${ }^{2}$ Evaluated at the test day preceding enrollment.

cows diagnosed with chronic CM during the follow-up period was reduced $(P=0.02)$ by injectable trace mineral supplementation in first-lactation cows, but not in cows with 2 or more lactations. Based on survival analyses, treatment had no effect on interval to removal from the herd (Figure 1).

\section{Mineral Concentrations in Serum According to Disease Status}

When animals were compared according to disease status regardless of treatment group, cows that recovered from SCM within $30 \mathrm{~d}$ of study had higher $(P$ $=0.04$ ) concentrations of calcium and tended to have lower $(P=0.10)$ concentrations of zinc in serum at enrollment compared with herdmates that did not recover from the disease (Table 7). Cure of SCM was associated with higher $(P \leq 0.01)$ serum concentrations of phosphorus and selenium on d 30. Serum concentrations of the remaining minerals did not differ between cows that recovered from SCM and herdmates that did not recover from the disease. We found difference in serum mineral concentrations between cows that developed
$\mathrm{CM}$ and herdmates without clinical signs of the disease (Table 8).

\section{Milk Yield and Composition}

Injectable trace mineral supplementation did not improve milk production during the follow-up period, which averaged $35.1 \pm 0.5 \mathrm{~kg}$ for CTRL and $34.5 \pm$ $0.5 \mathrm{~kg}$ for ITMS cows. Furthermore, milk yield was not affected by lactation group or the interaction between treatment and lactation group. Treatment and the interaction between treatment and lactation group had no effect on milk fat $(\mathrm{CTRL}=3.91 \pm 0.03$ vs. ITMS $=3.93 \pm 0.03 \%)$ and protein content $(\mathrm{CTRL}=3.20 \pm$ 0.02 vs. ITMS $=3.20 \pm 0.02 \%$ ). Milk fat content was greater $(P<0.03)$ for first- as well as second-lactation cows compared with those with 3 or more lactations $(3.97 \pm 0.03,3.96 \pm 0.03$, and $3.82 \pm 0.04 \%$, respectively). Milk protein content was also affected by lactation group because second-lactation $(3.25 \pm 0.02 \%)$ cows had higher $(P<0.02)$ concentrations compared with first-lactation cows and those with 3 or more lactations $(3.19 \pm 0.02$ and $3.15 \pm 0.02 \%$, respectively). 


\section{DISCUSSION}

Although injectable trace mineral supplementation containing selenium, copper, zinc, and manganese during the prepartum period has been shown to reduce SCC throughout the first 5 mo of lactation (Machado et al., 2013), its effects on health and productive performance of lactating dairy cows diagnosed with SCM remains elusive. The requirements for trace minerals in lactating dairy cow diets have been calculated based on studies that focused in reproductive performance, milk production, and stability of skeletal system, rather than targeting optimum immune function. To the best of our knowledge, only copper and selenium had aspects of the immune function taken into consideration during requirement calculation. Therefore, it is possible that the trace minerals needed for optimum udder health have been underestimated. It is important to highlight that, in the present study, mineral status of the study population was assessed through blood mineral panel analysis in a subset of animals at enrollment and all blood concentrations of minerals evaluated were in accordance with previously reported normal values (Dargatz and Ross, 1996; Kincaid, 2000; NRC, 2001).

Table 3. Mineral concentrations in serum of cows diagnosed with subclinical mastitis (SCC $\geq 200 \times 10^{3}$ cells $/ \mathrm{mL}$ ) based on the test day preceding enrollment by treatment group ${ }^{1}$

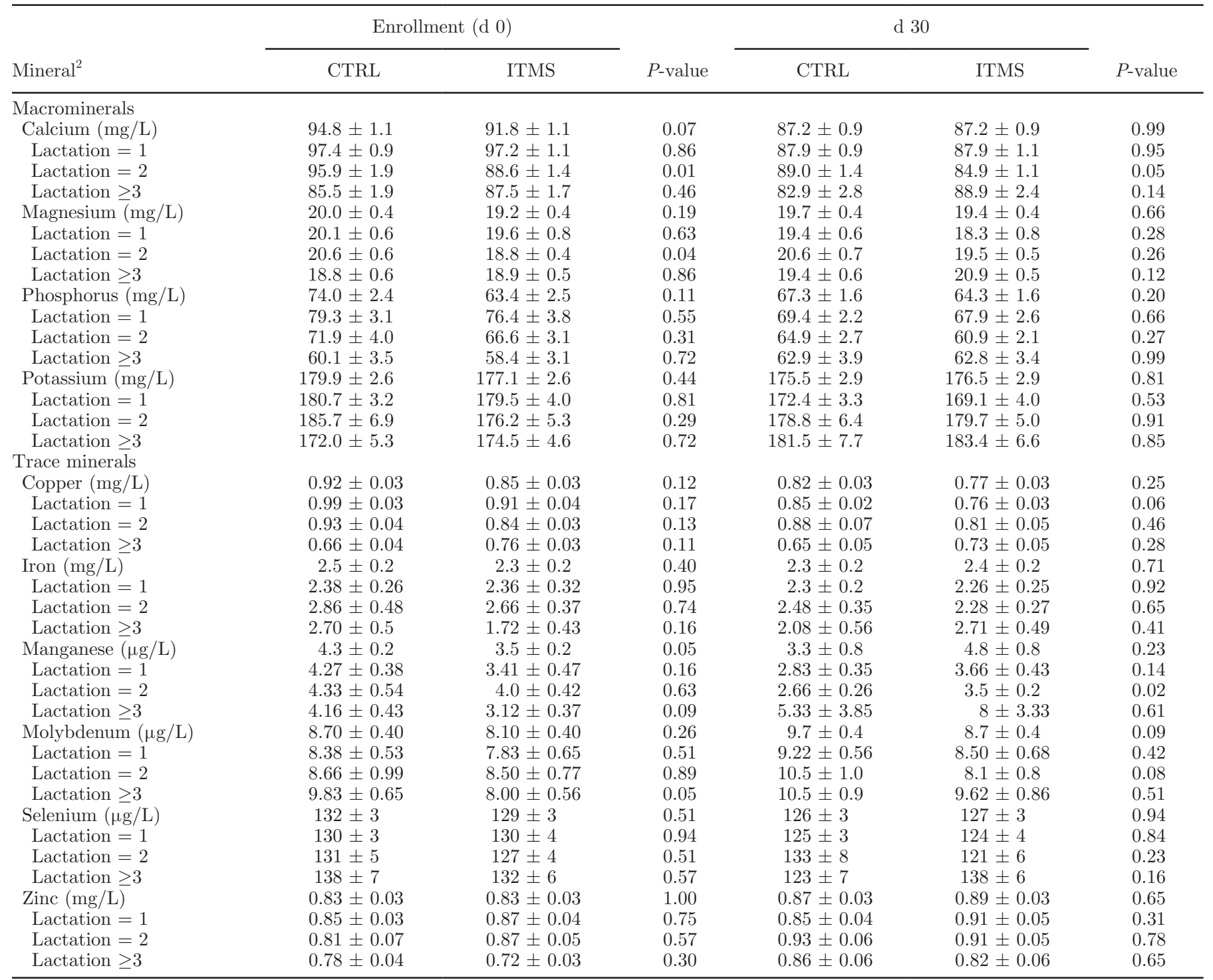

${ }^{1} \mathrm{CTRL}=$ cows received no trace mineral supplementation $(\mathrm{n}=30)$; ITMS $=$ cows received a single injectable trace mineral supplementation containing zinc $(300 \mathrm{mg})$, manganese $(50 \mathrm{mg})$, selenium $(25 \mathrm{mg})$, and copper $(75 \mathrm{mg})$ at enrollment (lactation $=1$ : CTRL $\mathrm{n}=18$ and ITMS $\mathrm{n}=12$; lactation $=2$ : CTRL $\mathrm{n}=6$ and ITMS $\mathrm{n}=10$; lactation $\geq 3$ : CTRL $\mathrm{n}=6$ and ITMS $\mathrm{n}=8$ ). Results are presented as LSM \pm SEM.

${ }^{2}$ Values in each header row represent the overall mineral concentrations of each named mineral (including all lactations). 
Table 4. Logistic regression model for the effect of injectable trace mineral supplementation on subclinical mastitis cure (SCC $<200 \times 10^{3}$ cells $/ \mathrm{mL}$ ) of cows diagnosed with subclinical mastitis (SCC $\geq 200 \times 10^{3}$ cells/ $\mathrm{mL}$ ) on the test day preceding enrollment ${ }^{1}$

\begin{tabular}{|c|c|c|c|c|}
\hline Variable & Level & Cured $^{2}[\%(\mathrm{n})]$ & $\mathrm{OR}^{3}$ & $P$-value \\
\hline Treatment & $\begin{array}{l}\text { CTRL } \\
\text { ITMS }\end{array}$ & $\begin{array}{l}42.8(314) \\
46.5(306)\end{array}$ & $\begin{array}{c}\text { Reference } \\
1.16\end{array}$ & 0.38 \\
\hline Parity & $\begin{array}{l}\text { Lactation }=1 \\
\text { Lactation }=2 \\
\text { Lactation } \geq 3\end{array}$ & $\begin{array}{l}58.5(240) \\
42.8(215) \\
33.2(165)\end{array}$ & $\begin{array}{c}\text { Reference } \\
0.53 \\
0.35\end{array}$ & $<0.001$ \\
\hline Parity $\times$ treatment & $\begin{array}{l}\text { Lactation }=1-\text { CTRL } \\
\text { Lactation }=1 \text { - ITMS } \\
\text { Lactation }=2 \text { - CTRL } \\
\text { Lactation }=2 \text { - ITMS } \\
\text { Lactation } \geq 3 \text { - CTRL } \\
\text { Lactation } \geq 3 \text { - ITMS }\end{array}$ & $\begin{array}{l}60.6(109) \\
56.5(131) \\
42.5(120) \\
43.2(95) \\
27.1(85) \\
40.0(80)\end{array}$ & $\begin{array}{c}\text { Reference } \\
0.85 \\
\text { Reference } \\
1.03 \\
\text { Reference } \\
1.80\end{array}$ & $\begin{array}{l}0.53 \\
0.92\end{array}$ \\
\hline
\end{tabular}

${ }^{1} \mathrm{CTRL}=$ cows received no trace mineral supplementation $(\mathrm{n}=314)$; ITMS $=$ cows received a single injectable trace mineral supplementation containing zinc $(300 \mathrm{mg})$, manganese $(50 \mathrm{mg})$, selenium $(25 \mathrm{mg})$, and copper $(75 \mathrm{mg})$ at enrollment $(\mathrm{n}=306)$.

${ }^{2}$ Data presented as proportions adjusted by the logistic regression model.

${ }^{3}$ Odds ratios (OR) from the logistic regression model.

Mineral supplementation in lactating dairy cows with normal levels of blood minerals and with SCC $\geq 200$ $\times 10^{3}$ cells $/ \mathrm{mL}$ significantly reduced the incidence of chronic CM in primiparous cows, tended to reduce overall incidence of chronic CM, and tended to improve SCM cure in cows with 3 or more lactations. Nevertheless, ITMS did not significantly affect survival, milk yield, or milk composition in cows diagnosed with SCM.

Genther and Hansen (2014) supplemented beef steers with the same mineral combination used in the present study and reported increases in circulating concentrations of manganese and selenium for 1 and $15 \mathrm{~d}$ following injection, respectively. Similar to our results, that group did not observe differences in serum mineral concentrations between treatment and control groups on d 29 postinjection; however, liver copper and selenium contents were higher in supplemented steers. One explanation for the similar blood mineral concentrations between ITMS and CTRL groups in the current trial could be the timing of sample collection. Supplemental minerals in ITMS could have been cleared through homeostatic processes or have been stored in body reserves. Given the circumstances of the present study, it was not possible to perform liver biopsies on d 30 to assess the effect of ITMS on other body reserves.

Our results indicate that the administration of ITMS can be used as a strategy to lower the incidence of chronic CM in primiparous cows diagnosed with elevated SCC. The importance of trace minerals in the immune system and mammary health has been

Table 5. Logistic regression model for the effect of injectable trace mineral supplementation on the incidence of clinical mastitis in cows diagnosed with subclinical mastitis ( $\mathrm{SCC} \geq 200 \times 10^{3}$ cells $/ \mathrm{mL}$ ) on the test day preceding enrollment ${ }^{1}$

\begin{tabular}{|c|c|c|c|c|}
\hline Variable & Level & $\mathrm{CM}^{2}[\%(\mathrm{n})]$ & $\mathrm{OR}^{3}$ & $P$-value \\
\hline \multirow[t]{2}{*}{ Treatment } & CTRL & $48.2(314)$ & Reference & 0.11 \\
\hline & ITMS & $41.7(306)$ & 0.77 & \\
\hline \multirow[t]{3}{*}{ Parity } & Lactation $=1$ & $42.0(240)$ & Reference & 0.30 \\
\hline & Lactation $=2$ & $43.3(215)$ & 1.05 & \\
\hline & Lactation $\geq 3$ & $49.5(165)$ & 1.36 & \\
\hline \multirow[t]{6}{*}{ Parity $\times$ treatment } & Lactation $=1-$ CTRL & $45.9(109)$ & Reference & 0.23 \\
\hline & Lactation $=1-$ ITMS & $38.2(131)$ & 0.73 & \\
\hline & Lactation $=2-\mathrm{CTRL}$ & $43.3(120)$ & Reference & 0.98 \\
\hline & Lactation $=2-$ ITMS & $43.2(95)$ & 0.99 & \\
\hline & Lactation $\geq 3$ - CTRL & $55.3(85)$ & Reference & 0.14 \\
\hline & Lactation $\geq 3$ - ITMS & $43.8(80)$ & 0.63 & \\
\hline
\end{tabular}

${ }^{1} \mathrm{CTRL}=$ cows received no trace mineral supplementation $(\mathrm{n}=314) ;$ ITMS $=$ cows received a single injectable trace mineral supplementation containing zinc $(300 \mathrm{mg})$, manganese $(50 \mathrm{mg})$, selenium $(25 \mathrm{mg})$, and copper $(75 \mathrm{mg})$ at enrollment $(\mathrm{n}=306)$.

${ }^{2}$ Clinical mastitis (CM) was defined as abnormal milk with clots in a forestripping test. Adjusted proportions according to the logistic regression model.

${ }^{3}$ Odds ratios (OR) from the logistic regression model. 
Table 6. Logistic regression model for the effect of injectable trace mineral supplementation on the incidence of chronic clinical mastitis in cows diagnosed with subclinical mastitis ( $\mathrm{SCC} \geq 200 \times 10^{3}$ cells $/ \mathrm{mL}$ ) on the test day preceding enrollment ${ }^{1}$

\begin{tabular}{|c|c|c|c|c|}
\hline Variable & Level & $\mathrm{CCM}^{2}[\%(\mathrm{n})]$ & $\mathrm{OR}^{3}$ & $P$-value \\
\hline \multirow[t]{2}{*}{ Treatment } & CTRL & $16.9(314)$ & Reference & 0.09 \\
\hline & ITMS & $12.0(306)$ & 0.67 & \\
\hline \multirow[t]{3}{*}{ Parity } & Lactation $=1$ & $12.0(240)$ & Reference & 0.13 \\
\hline & Lactation $=2$ & $12.7(215)$ & 1.06 & \\
\hline & Lactation $\geq 3$ & $18.9(165)$ & 1.71 & \\
\hline \multirow[t]{6}{*}{ Parity $\times$ treatment } & Lactation $=1-$ CTRL & $18.4(109)$ & Reference & 0.02 \\
\hline & Lactation $=1-$ ITMS & $7.6(131)$ & 0.37 & \\
\hline & Lactation $=2-$ CTRL & $10.8(120)$ & Reference & 0.39 \\
\hline & Lactation $=2-$ ITMS & $14.7(95)$ & 1.42 & \\
\hline & Lactation $\geq 3$ - CTRL & $23.5(85)$ & Reference & 0.17 \\
\hline & Lactation $\geq 3$ - ITMS & $15.0(80)$ & 0.57 & \\
\hline
\end{tabular}

${ }^{1} \mathrm{CTRL}=$ cows received no trace mineral supplementation $(\mathrm{n}=314)$; ITMS $=$ cows received a single injectable trace mineral supplementation containing zinc $(300 \mathrm{mg})$, manganese $(50 \mathrm{mg})$, selenium $(25 \mathrm{mg})$, and copper (75 mg) at enrollment $(\mathrm{n}=306)$.

${ }^{2}$ Chronic clinical mastitis (CCM) was defined as 3 or more cases of clinical mastitis. All cows included in the study were diagnosed with subclinical mastitis ( $\mathrm{SCC} \geq 200 \times 10^{3}$ cells $/ \mathrm{mL}$ ) on the test day preceding enrollment. Adjusted proportions from the logistic regression model.

${ }^{3}$ Odds ratios (OR) from the logistic regression model.

reported in several studies (Andrieu, 2008; O'Rourke, 2009; Overton and Yasui, 2014). Elevated SCC has been associated with greater odds of developing CM (Peeler et al., 2003). Previous work from our group reported significantly lower odds of developing CM in multiparous animals that received injectable trace mineral supplementation containing selenium, copper, zinc, and manganese during the dry period (Machado et al., 2013). The differences found between the results presented here and data reported by Machado et al. (2013) might be due to dissimilarities in the target population and the frequency of supplementation between studies. We supplemented lactating animals experiencing SCM with a single dose of ITMS, whereas the former work

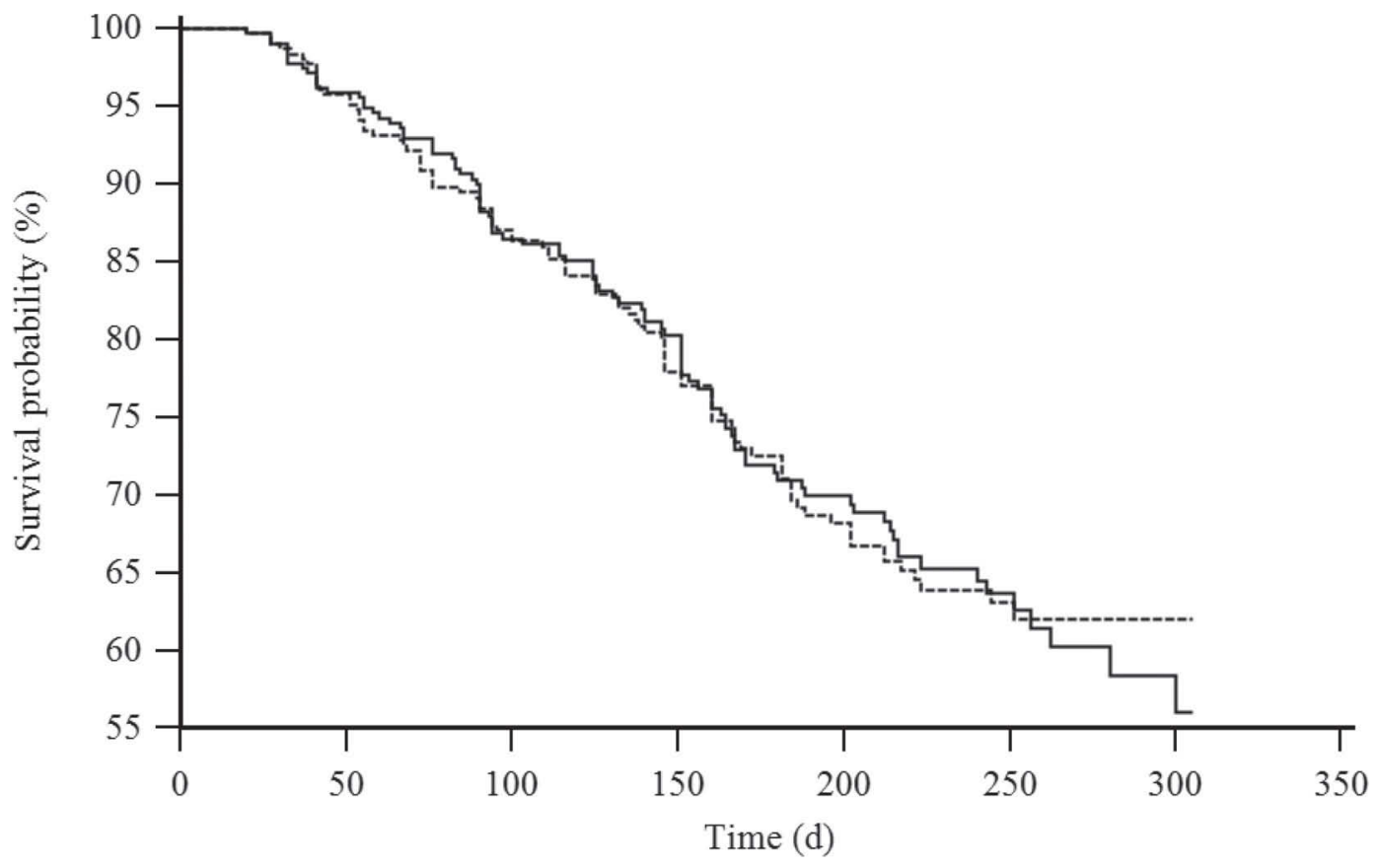

Figure 1. Kaplan-Meier survival analysis of time from enrollment to removal from the herd. CTRL $=$ cows with subclinical mastitis that received no mineral supplementation $(\mathrm{n}=314$; solid line); ITMS $=$ cows with subclinical mastitis treated with an injectable trace mineral supplement (zinc, $300 \mathrm{mg}$; manganese, $50 \mathrm{mg}$; selenium, $25 \mathrm{mg}$; copper, $75 \mathrm{mg})$ on d 0 ( $\mathrm{n}=306$; dashed line). The mean enrollment to removal from the herd intervals were 239.6 and $239.3 \mathrm{~d}$ for CTRL and ITMS, respectively $(P=0.94)$. 
Table 7. Mineral concentrations in serum according to cure of subclinical mastitis (SCM) ${ }^{1}$

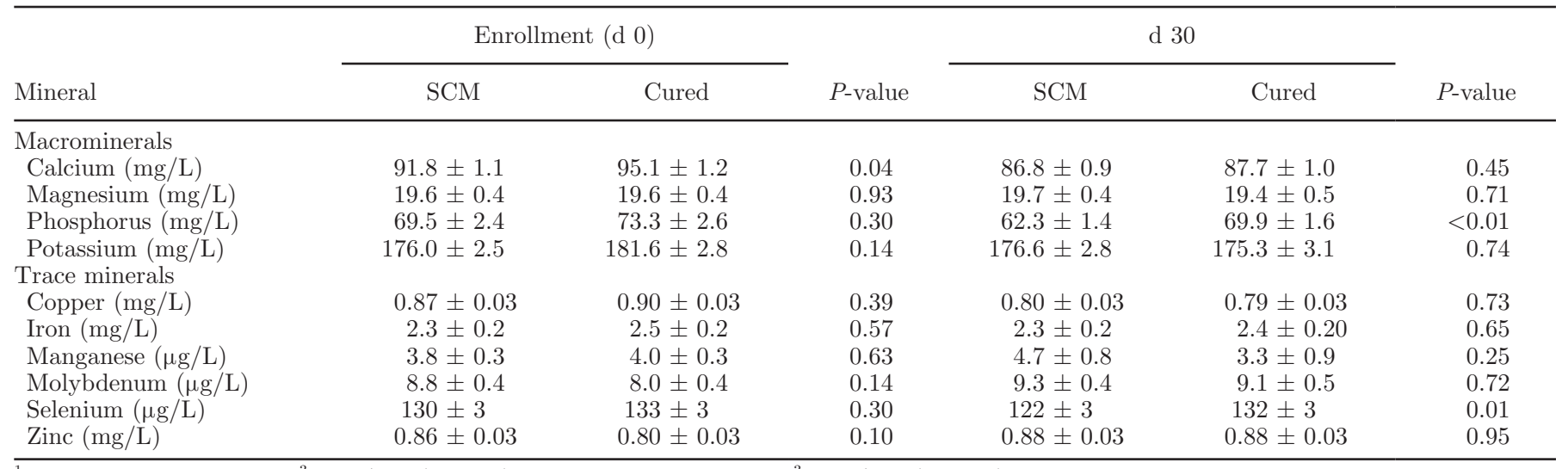

${ }^{1}$ Cured $=\mathrm{SCC}<200 \times 10^{3}$ cells $/ \mathrm{mL}(\mathrm{n}=27) . \mathrm{SCM}=\mathrm{SCC} \geq 200 \times 10^{3}$ cells $/ \mathrm{mL}(\mathrm{n}=33)$. All cows were diagnosed with subclinical mastitis $\left(\mathrm{SCC} \geq 200 \times 10^{3}\right.$ cells $/ \mathrm{mL}$ ) on the test day preceding enrollment. Results are presented as LSM $\pm \mathrm{SEM}$.

aimed to evaluate the effect of a 3 doses supplementation of healthy cows during the transition period. In that study, injectable trace mineral supplementation containing selenium, copper, zinc, and manganese was given at approximately 230 and $260 \mathrm{~d}$ of gestation and again at 35 DIM.

In the present study, injectable trace mineral supplementation of selenium, copper, zinc, and manganese also tended to increase SCM cure in cows of third or greater lactation. We observed that this group of animals had the lowest initial serum concentrations of copper, calcium, and phosphorus. Cows of third or greater lactation were also the highest milk-producing group; therefore, mineral requirements for those animals could possibly have been underestimated, and might explain why the supplementation with ITMS had an effect of SCM cure in this group.

When animals were compared across treatments based on disease status, serum concentration of selenium on d 30 was lower in animals that remained affected with SCM. Selenium is an essential element of the antioxidant enzymes glutathione peroxidase and thioredoxin reductase, playing a role in regulation and host cell resistance to reactive oxygen species (McKenzie et al., 2002). Nonetheless, all animals in the present study had adequate selenium levels at both time points. In dairy cows, selenium supplementation has been associated with better neutrophil function (Ibeagha et al., 2009), decreased prevalence of mammary infections (Erskine et al., 1987; Jukola et al., 1996), and improved antioxidant status and immune function (Hall et al., 2014). Studies that used supplementation of bovine mammary cells in vitro suggested that selenium supplementation plays a role in the optimization of udder health in via increased resistance to oxidative stress (Miranda et al., 2011).

In addition to differences in selenium status between cows that underwent SCM cure and those that remained

Table 8. Mineral concentrations in serum according to occurrence of clinical mastitis (CM) in cows diagnosed with subclinical mastitis (SCC $\geq 200 \times 10^{3}$ cells $/ \mathrm{mL}$ ) on the test day preceding enrollment ${ }^{1}$

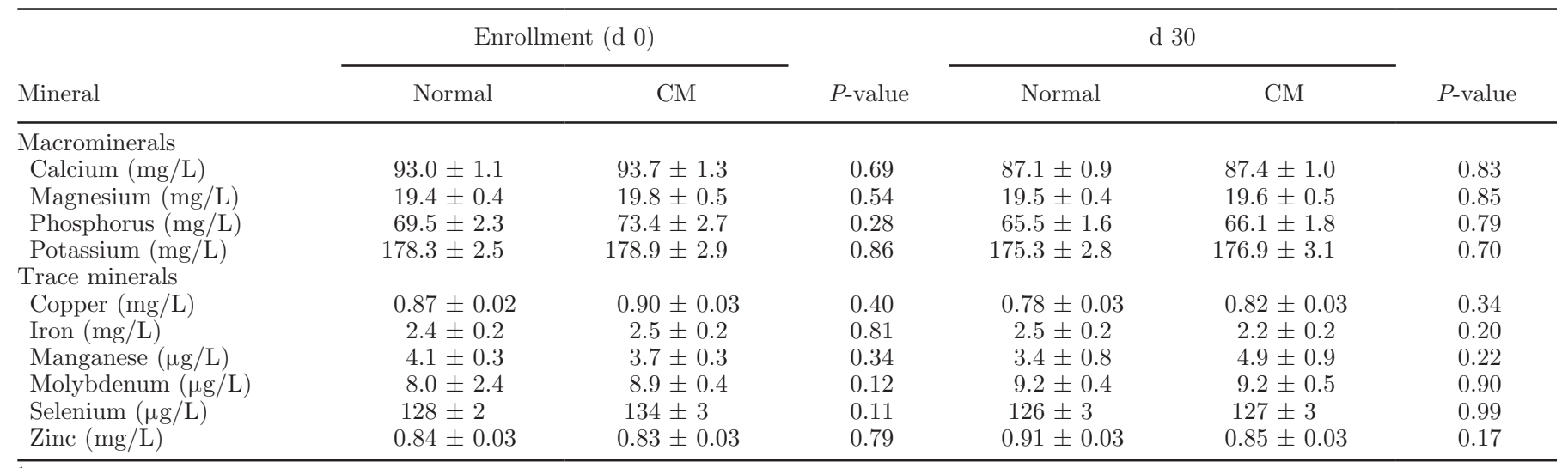

${ }^{1} \mathrm{CM}=$ animals with abnormal milk during a forestripping test $(\mathrm{n}=26)$; Normal = cows that had normal milk at every test during the follow-up period $(\mathrm{n}=34)$. Results are presented as LSM \pm SEM 
with SCC above $200 \times 10^{3}$ cells $/ \mathrm{mL}$, associations between macrominerals concentrations and mammary gland health were observed. We identified that cows that experienced SCM cure had higher concentrations of serum calcium on d 0. Circulating calcium levels have been associated with bovine immune function and disease status in other studies (Curtis et al., 1983; Kimura et al., 2006; Martinez et al., 2012). A study conducted in Florida reported that neutrophils isolated from cows with lower serum calcium in the transition period had impaired in vitro phagocytosis and bacterial-killing capacity, fewer circulating leucocytes, a more pronounced decrease in neutrophil count postpartum, and increased incidence of metritis (Martinez et al., 2012). That group evaluated the effects of subclinical hypocalcemia in dairy cows; however, it is important to highlight that the study population herein had levels of calcium above of the cutoff of $8.59 \mathrm{mg} / \mathrm{dL}$, for which a cow was considered subclinically hypocalcemic. Nevertheless, circulating calcium levels have been directly correlated with amounts of releasable calcium in the endoplasmic reticulum (Kimura et al., 2006), playing a role in bovine neutrophil activation, reactive oxygen species production, and degranulation, all of which are critical for proper immune function (Tintinger et al., 2005; Burgos et al., 2011).

In the present study, higher phosphorus concentrations were associated with SCM cure. Cows that recovered from the disease by d 30 had higher serum concentrations of phosphorus on d 30 compared with those that remained with $\mathrm{SCC} \geq 200 \times 10^{3}$ cells $/ \mathrm{mL}$. Limited research associating phosphorus and bovine immune function is available. Mullarky et al. (2009) found that supplementing lactating dairy cows with no (0.34\%, no supplementary P), medium (0.43\%), or high $(0.52 \%)$ levels of phosphorus did not influence lymphocyte proliferation and neutrophil-killing ability in vitro. Further research is necessary to evaluate the effect of phosphorus supplementation beyond required levels in dairy cow immune function.

Although copper and zinc levels were not different between treatment groups nor associated with SCM cure or decreased odds of chronic CM; it is well known that these minerals are components of the enzyme superoxide dismutase, which has been previously associated with udder health (Machado et al., 2014). Additionally, Blanco-Penedo et al. (2014) reported that herds with low manganese had increased odds of CM as compared with herds with adequate levels of manganese, and that low copper levels were associated with increased odds of CM cases for second lactation cows. Nevertheless, we cannot exclude the possibility of multiple factors, other than a specific mineral level, playing a role in associations observed in survey-type studies, such as the one conducted by Blanco-Penedo et al. (2014). Further research is necessary to evaluate repeated ITMS supplementation to lactating dairy cows with elevated SCC belonging to various parity groups. Perhaps the administration of sequential doses of ITMS to animals with SCM would be effective in providing supplemental trace minerals for improved udder health.

\section{CONCLUSIONS}

A single subcutaneous injection containing zinc, manganese, selenium, and copper administered to dairy cows with elevated SCC reduced the incidence of chronic CM, particularly in primiparous cows, and tended to increase SCM cure in cows with 3 or more lactations. Supplementation had no effect on milk production and composition in cows with elevated SCC. Regardless of supplementation, cows that were cured of SCM had lower serum concentrations of zinc at diagnosis and higher selenium and phosphorus concentrations 30 d later compared with herdmates that maintained SCC above $200 \times 10^{3}$ cells $/ \mathrm{mL}$, thereby supporting a possible role for availability and utilization of trace minerals for maintenance of udder health.

\section{ACKNOWLEDGMENTS}

The authors thank the owners and staff of the experimental herd for their assistance with experimental procedures and excellent record keeping. This study was funded by Multimin North America Inc. (Fort Collins, CO).

\section{REFERENCES}

Andrieu, S. 2008. Is there a role for organic trace element supplements in transition cow health? Vet. J. 176:77-83.

Bar, D., L. W. Tauer, G. Bennett, R. N. Gonzalez, J. A. Hertl, Y. H. Schukken, H. F. Schulte, F. L. Welcome, and Y. T. Grohn. 2008. The cost of generic clinical mastitis in dairy cows as estimated by using dynamic programming. J. Dairy Sci. 91:2205-2214.

Barlow, J. W., L. J. White, R. N. Zadoks, and Y. H. Schukken. 2009. A mathematical model demonstrating indirect and overall effects of lactation therapy targeting subclinical mastitis in dairy herds. Prev. Vet. Med. 90:31-42.

Bicalho, M. L., F. S. Lima, E. K. Ganda, C. Foditsch, E. B. Meira Jr., V. S. Machado, A. G. Teixeira, G. Oikonomou, R. O. Gilbert, and R. C. Bicalho. 2014. Effect of trace mineral supplementation on selected minerals, energy metabolites, oxidative stress, and immune parameters and its association with uterine diseases in dairy cattle. J. Dairy Sci. 97:4281-4295.

Blanco-Penedo, I., T. Lundh, K. Holtenius, N. Fall, and U. Emanuelson. 2014. The status of essential elements and associations with milk yield and the occurrence of mastitis in organic and conventional dairy herds. Livest. Sci. 168:120-127.

Boland, F., L. O'Grady, and S. J. More. 2013. Investigating a dilution effect between somatic cell count and milk yield and estimating milk production losses in Irish dairy cattle. J. Dairy Sci. 96:1477-1484. 
Burgos, R. A., I. Conejeros, M. A. Hidalgo, D. Werling, and C. Hermosilla. 2011. Calcium influx, a new potential therapeutic target in the control of neutrophil-dependent inflammatory diseases in bovines. Vet. Immunol. Immunopathol. 143:1-10.

Curtis, C. R., H. N. Erb, C. J. Sniffen, R. D. Smith, P. A. Powers, M. C. Smith, M. E. White, R. B. Hillman, and E. J. Pearson. 1983. Association of parturient hypocalcemia with eight periparturient disorders in Holstein cows. J. Am. Vet. Med. Assoc. 183:559-561.

Dargatz, D. A., and P. F. Ross. 1996. Blood selenium concentrations in cows and heifers on 253 cow-calf operations in 18 states. J. Anim. Sci. 74:2891-2895.

Deluyker, H. A., J. M. Gay, and L. D. Weaver. 1993. Interrelationships of somatic cell count, mastitis, and milk yield in a low somatic cell count herd. J. Dairy Sci. 76:3445-3452.

Edmonson, A., I. Lean, L. Weaver, T. Farver, and G. Webster. 1989. A body condition scoring chart for Holstein dairy cows. J. Dairy Sci. 72:68-78.

Erskine, R. J., R. J. Eberhart, L. J. Hutchinson, and R. W. Scholz. 1987. Blood selenium concentrations and glutathione peroxidase activities in dairy herds with high and low somatic cell counts. J. Am. Vet. Med. Assoc. 190:1417-1421.

Genther, O. N., and S. L. Hansen. 2014. A multielement trace mineral injection improves liver copper and selenium concentrations and manganese superoxide dismutase activity in beef steers. J. Anim. Sci. 92:695-704.

Grasso, P. J., R. W. Scholz, R. J. Erskine, and R. J. Eberhart. 1990. Phagocytosis, bactericidal activity, and oxidative metabolism of milk neutrophils from dairy cows fed selenium-supplemented and selenium-deficient diets. Am. J. Vet. Res. 51:269-274.

Green, L. E., Y. H. Schukken, and M. J. Green. 2006. On distinguishing cause and consequence: Do high somatic cell counts lead to lower milk yield or does high milk yield lead to lower somatic cell count? Prev. Vet. Med. 76:74-89.

Hagnestam-Nielsen, C., and S. Ostergaard. 2009. Economic impact of clinical mastitis in a dairy herd assessed by stochastic simulation using different methods to model yield losses. Animal 3:315-328.

Halasa, T., M. Nielen, A. P. De Roos, R. Van Hoorne, G. de Jong, T. J. Lam, T. van Werven, and H. Hogeveen. 2009. Production loss due to new subclinical mastitis in Dutch dairy cows estimated with a test-day model. J. Dairy Sci. 92:599-606.

Hall, J. A., G. Bobe, W. R. Vorachek, K. Kasper, M. G. Traber, W. D. Mosher, G. J. Pirelli, and M. Gamroth. 2014. Effect of supranutritional organic selenium supplementation on postpartum blood micronutrients, antioxidants, metabolites, and inflammation biomarkers in selenium-replete dairy cows. Biol. Trace Elem. Res. $161: 272-287$

Hogan, J. S., K. L. Smith, W. P. Weiss, D. A. Todhunter, and W. L. Schockey. 1990. Relationships among vitamin E, selenium, and bovine blood neutrophils. J. Dairy Sci. 73:2372-2378.

Ibeagha, A. E., E. M. Ibeagha-Awemu, J. Mehrzad, B. Baurhoo, P. Kgwatalala, and X. Zhao. 2009. The effect of selenium sources and supplementation on neutrophil functions in dairy cows. Animal 3:1037-1043.

Jukola, E., J. Hakkarainen, H. Saloniemi, and S. Sankari. 1996. Blood selenium, vitamin $\mathrm{E}$, vitamin $\mathrm{A}$, and beta-carotene concentrations and udder health, fertility treatments, and fertility. J. Dairy Sci. 79:838-845.

Kimura, K., T. A. Reinhardt, and J. P. Goff. 2006. Parturition and hypocalcemia blunts calcium signals in immune cells of dairy cattle. J. Dairy Sci. 89:2588-2595.
Kincaid, R. L. 2000. Assessment of trace mineral status of ruminants: A review. J. Anim. Sci. 77:1-10.

Kommisrud, E., O. Osteras, and T. Vatn. 2005. Blood selenium associated with health and fertility in Norwegian dairy herds. Acta Vet. Scand. 46:229-240.

Machado, V. S., M. L. Bicalho, R. V. Pereira, L. S. Caixeta, W. A. Knauer, G. Oikonomou, R. O. Gilbert, and R. C. Bicalho. 2013. Effect of an injectable trace mineral supplement containing selenium, copper, zinc, and manganese on the health and production of lactating Holstein cows. Vet. J. 197:451-456.

Machado, V. S., G. Oikonomou, S. F. Lima, M. L. Bicalho, C. Kacar, C. Foditsch, M. J. Felippe, R. O. Gilbert, and R. C. Bicalho. 2014. The effect of injectable trace minerals (selenium, copper, zinc, and manganese) on peripheral blood leukocyte activity and serum superoxide dismutase activity of lactating Holstein cows. Vet. J. 200:299-304.

Martinez, N., C. A. Risco, F. S. Lima, R. S. Bisinotto, L. F. Greco, E. S. Ribeiro, F. Maunsell, K. Galvao, and J. E. Santos. 2012. Evaluation of peripartal calcium status, energetic profile, and neutrophil function in dairy cows at low or high risk of developing uterine disease. J. Dairy Sci. 95:7158-7172.

McKenzie, R. C., J. R. Arthur, and G. J. Beckett. 2002. Selenium and the regulation of cell signaling, growth, and survival: Molecular and mechanistic aspects. Antioxid. Redox Signal. 4:339-351.

Miranda, S. G., N. G. Purdie, V. R. Osborne, B. L. Coomber, and J. P. Cant. 2011. Selenomethionine increases proliferation and reduces apoptosis in bovine mammary epithelial cells under oxidative stress. J. Dairy Sci. 94:165-173.

Mullarky, I. K., W. A. Wark, M. Dickenson, S. Martin, C. S. Petersson-Wolfe, and K. F. Knowlton. 2009. Short communication: analysis of immune function in lactating dairy cows fed diets varying in phosphorus content. J. Dairy Sci. 92:365-368.

NRC. 2001. Nutrient Requirements of Dairy Cattle. 7 th rev. ed. Natl. Acad. Press, Washington, DC.

O'Rourke, D. 2009. Nutrition and udder health in dairy cows: A review. Ir. Vet. J. 62(Suppl 4):S15-S20.

Overton, T. R., and T. Yasui. 2014. Practical applications of trace minerals for dairy cattle. J. Anim. Sci. 92:416-426.

Peeler, E. J., M. J. Green, J. L. Fitzpatrick, and L. E. Green. 2003. The association between quarter somatic-cell counts and clinical mastitis in three British dairy herds. Prev. Vet. Med. 59:169-180.

Scaletti, R. W., D. S. Trammell, B. A. Smith, and R. J. Harmon. 2003. Role of dietary copper in enhancing resistance to Escherichia coli mastitis. J. Dairy Sci. 86:1240-1249.

Tintinger, G., H. C. Steel, and R. Anderson. 2005. Taming the neutrophil: calcium clearance and influx mechanisms as novel targets for pharmacological control. Clin. Exp. Immunol. 141:191-200.

Torre, P. M., R. J. Harmon, R. W. Hemken, T. W. Clark, D. S. Trammell, and B. A. Smith. 1996. Mild dietary copper insufficiency depresses blood neutrophil function in dairy cattle. J. Nutr. Immunol. 4:3-24.

Weiss, W. P., J. S. Hogan, K. L. Smith, and K. H. Hoblet. 1990. Relationships among selenium, vitamin E, and mammary gland health in commercial dairy herds. J. Dairy Sci. 73:381-390.

White, L. J., T. J. Lam, Y. H. Schukken, L. E. Green, G. F. Medley, and M. J. Chappell. 2006. The transmission and control of mastitis in dairy cows: a theoretical approach. Prev. Vet. Med. 74:67-83. 